\title{
A Multi-Level Framework for Adaptation to Drought Within Temperate Agriculture
}

\author{
IP Holman *, TM Hess, D Rey and JW Knox \\ Cranfield Water Science Institute, Cranfield University, Bedford, United Kingdom
}

OPEN ACCESS

Edited by:

Ranjan Kumar Ghosh, Indian Institute of Management Ahmedabad, India

Reviewed by:

Nedumaran Swamikannu, International Crops Research Institute for the Semi-Arid Tropics (ICRISAT),

India

Tabea Katharina Lissner, Climate Analytics GmbH, Germany

*Correspondence: IP Holman

i.holman@cranfield.ac.uk

Specialty section:

This article was submitted to

Environmental Economics and Management,

a section of the journa

Frontiers in Environmental Science

Received: 25 August 2020 Accepted: 11 December 2020

Published: 20 January 2021

Citation:

Holman IP, Hess TM, Rey D and Knox JW (2021) A Multi-Level Framework for Adaptation to Drought

Within Temperate Agriculture.

Front. Environ. Sci. 8:589871.

doi: $10.3389 /$ fenvs.2020.589871
Droughts affect a range of economically important sectors but their impacts are usually most evident within agriculture. Agricultural impacts are not confined to arid and semi-arid regions, but are increasingly experienced in more temperate and humid regions. A transferable drought management framework is needed to transition from coping to adapting to drought through supporting improved planning and policy decision-making through the supply chain from primary producers to consumers. A combination methodology using a Driver-Pressure-State-Impact-Response (DPSIR) approach, an analysis of weekly agricultural trade publications and semi-structured interviews were used to explore drought impacts and responses, using the 2018 United Kingdom drought as a case study. While most reported responses were on-farm, a diverse range of measures were implemented across institutional scales and through the supply chain, reflecting complex interactions within the food system. However, drought responses were dominated by reactive and crisis-driven actions to cope with, or enhance the recovery from, drought; but which contributed little to increased resilience to future droughts. Our transferable drought management framework shows how improved collaboration and multi-sector engagement across spatial, governance and supply-chain scales to develop human and social capital can enable the transition from coping (short-term and reactive) to adapting (long-term and anticipatory) strategies to increase agricultural resilience to future droughts.

Keywords: adaptation, cropping, impacts, irrigation, coping, livestock, resilience, drought

\section{INTRODUCTION}

Droughts are a serious natural hazard and widely recognized as being one of the dominant causes of global environmental, agricultural and economic damage (Vicente-Serrano et al., 2010). Although droughts affect a range of economically important sectors, their impacts are usually more evident within agriculture (Wilhite, 2007; FAO, 2017), including crop failure and reduced yields, abandoned farmland, increased soil degradation and reduced livestock fertility (and mortality) due to heat stress (Haro-Monteagudo et al., 2017). The impacts of an agricultural drought often also extend well beyond the farm gate, with drought-induced losses in food crop production at the farm level typically spreading along the value chain (e.g., Newton et al., 2011). Such drought impacts are not confined to arid and semi-arid regions (e.g., Azadi et al., 2018; Kuwayama et al., 2019), but increasingly experienced in more temperate and humid regions where droughts were historically not considered a major risk to agricultural sustainability (Bachmair et al., 2015; Rey et al., 2017; Parsons et al., 2019). However, increasing competition for water resources and a changing climate, with reduced rainfall 
reliability coupled with the increased probability of extreme events, is likely to exacerbate current drought risks ( $\mathrm{Lu}$ et al., 2019). Thus, there needs to be greater emphasis directed toward building resilience and adaptive capacity to cope with future drought events if potentially serious consequences for rural economies and food security are to be avoided.

In this current and forward-looking context, the development of drought risk management frameworks to support improved policy and planning for adaptation and resilience building appears both relevant and timely (Knox et al., 2020). However, such conceptual frameworks often tend to be geographically focused and highly regional (e.g., Morris et al., 2010; Papadimitriou et al., 2019), only consider specific sub-sectors (e.g., irrigated agriculture - Rey et al., 2017; Hess and Knox, 2013; outdoor livestock-Salmoral et al., 2020a) and focus on farm-level management interventions and responses (Morton and Barton, 2002; Hopkins and Del Prado, 2007; Meempatta et al., 2019), rather than addressing strategic or industry level needs. Recognizing both the multi-functional and multi-dimensional linkages that exist within agriculture and the nuances of drought that are unique to humid or temperate climates are also critically important aspects that warrant attention. Given these gaps in understanding, there is a need for a drought management framework that explicitly considers both the multi-scalar levels of governance and the wider range of actors that are engaged in humid or temperate agricultural systems.

This paper draws on our understanding of the drought impacts and responses of the United Kingdom food system, using the 2018 United Kingdom drought as an examplar, to develop such a transferable framework to contribute to and inform increased drought resilience. The United Kingdom is generally considered a "wet" country with sufficient rainfall to sustain crop production. Most outdoor agriculture is therefore dependent on rain fed production (Defra, 2018), but irrigated production is also regionally important (Rey et al., 2016). However, a number of significant droughts have occurred over the last 40 years with serious agronomic and financial impacts on United Kingdom agriculture. These include 1975-76, 1988-92, 1995-97, 2003, 2004-2006, 2010-2012 (Rey et al., 2017) and 2018. For example, the 2010-2012 drought caused an estimated

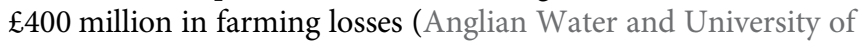
Cambridge, 2013) in England. In 2018, much of the United Kingdom (together with a significant wider area in Europe) suffered a combined heatwave and drought. For the United Kingdom as a whole, it was the equal warmest summer since records began in 1884 (and the hottest in England) with June being the driest in England since 1925 (Kendon et al., 2019). This led to a widespread agricultural drought across much of the United Kingdom, a water resources drought in some catchments, and a wide range of impacts and responses across the United Kingdom's diverse food system (NFU, 2018). Studies suggest that human-induced climate change has increased the likelihood of the 2018 heatwave/drought event (World Weather Attribution 2018; McCarthy et al., 2019), and that future droughts in Europe are projected to become more likely, extensive and prolonged due to climate change (Grillakis, 2019).
The approaches and framework developed here have wider application to other countries and regions where agriculture is an important component of the rural economy and where drought is an emergent risk to food production.

\section{METHODS AND DATA}

This paper uses a Driver-Pressure-State-Impact-Response (DPSIR) approach (Lange et al., 2017). Agrometeorological indices (Standardized Precipitation Index (SPI) and Potential Soil Moisture Deficit (PSMD)) were used to characterize the Drivers-Pressures that led to low soil moisture and river flows (State). A synthesis of reported drought Impacts and Responses to the 2018 drought were then combined with semi-structured interviews with key sector informants to elicit insights as to how drought impacts and multi-scale responses were influenced by food supply chain pressures. We then integrated these outputs, with our insights to develop a multi-scalar drought management framework that can inform a transition from reactive drought management to more pro-active approaches to increase agricultural drought resilience.

\section{Agroclimatic Characterization of the 2018 Drought}

We used two agrometeorological indicators to characterize the spatial severity and the temporal evolution of the 2018 drought. Firstly, the Standardized Precipitation Index (SPI) (McKee et al., 1993) is a drought severity indicator widely used internationally for drought monitoring (Barker et al., 2016). The SPI normalizes rainfall deficits based on the historic record, meaning the situation at a point in time is expressed relative to the past range of variability for the location in question. To represent the drought effects on the largely rain fed United Kingdom agricultural system, we used the 3-months SPI for July 2018, which provides a comparison of the precipitation in the May-July 2018 period with the precipitation totals from the same 3-month period for all the years included in the historical record. Increasingly negative values indicate a more severe, yet less likely, drought, with an SPI of $<-2.0$ representing "extremely dry" conditions with an expected probability of exceedence of around 2\% (WMO, 2012).

Secondly, we derived the temporal evolution in the potential soil moisture deficit (PSMD) which represents the cumulative interaction between precipitation and reference evapotranspiration (ETo):

$$
P S M D_{i}=P S M D_{i-1}+E T o_{i}-P_{i}
$$

Where;

$\operatorname{PSMD}_{\mathrm{i}}=$ potential soil moisture deficit at the end of day $\mathrm{i}(\mathrm{mm}) ; \mathrm{ETo}_{\mathrm{i}}=$ reference evapotranspiration on day $\mathrm{i}(\mathrm{mm})$ and $\mathrm{P}_{\mathrm{i}}=$ rainfall on day $\mathrm{i}(\mathrm{mm})$. PSMD on 1st January is set at zero.

The maximum PSMD in a given year $\left(\mathrm{PSMD}_{\max }\right)$ provides a useful aridity indicator for comparing individual years and has been extensively used as a drought index for irrigation planning 
(Knox et al., 1996) and climate impact assessments in agriculture (e.g., Rodriguez-Diaz et al., 2007; Chung et al., 2011). The $\mathrm{PSMD}_{\max }$ was calculated for two contrasting weather stations in the south-east (Cambridge-long-term average annual precipitation $=559 \mathrm{~mm}$ ) and north-west (Blackpool-long-term average annual precipitation $=846 \mathrm{~mm}$ ) of the country for 1976 and 2018 as well as the long term (1981-2010) average. The drought in 1976 is widely regarded as the most severe and extensive in the United Kingdom in living memory (Marsh et al., 2007; Rodda and Marsh, 2011) and was used as a comparison with 2018 .

\section{Synthesis of Drought Impacts From Farming Gray Literature}

Farmers Weekly and Farmers Guardian are the two main national weekly farmer-facing agricultural trade magazines published in the United Kingdom. They had an average circulation per issue of $>41,000$ and $>28,000$ in 2019, respectively, (ABC, 2020). For each magazine, potential drought-related text in each issue in 2018 was identified by keywords ("drought", "dry", "rainfall", "precipitation", "soil moisture", "scarcity", "stress", or "deficit") and extracted for reading and coding. The coding process led to the inductive identification of impact and response themes and sub-themes within the dataset (Salmoral et al., 2020b), following common practice in grounded theory (Patton, 1990; Bryant, 2014), which were iteratively refined as our understanding of the dataset increased. Classes of impacts and responses, and associated actors, were obtained based on the subject and context surrounding the text.

\section{Semi-Structured Interviews}

In terms of sensitivity to drought, the United Kingdom farming system can be broadly separated into enterprises where 1) crops are dependent on rainfall (rain fed), 2) livestock are dependent on rain fed grazing and fodder crops (livestock) and 3) farms where irrigation is used to supplement rainfall on crops (irrigated). Given this diversity and the complexity of supply chains, a series of targeted semi-structured interviews were conducted:

- Arable and horticultural cropping: sixteen interviews with individual key sectoral informants representing arable and horticultural interests, and covering rainfed (mostly combinable crops) and irrigated (potatoes, sugar beet, salads, field vegetables and protected horticulture) crops. The interviewees included growers within the main production areas across England, and informants within commercial and sectoral organizations with national coverage. Face to face interviews typically lasted around $30 \mathrm{~min}$.

- Outdoor livestock: twenty five interviews with individual livestock (beef, sheep and dairying) farmers at two livestock markets in Derbyshire. The length of each interview depended on the farmer's time commitments and willingness, but most lasted between 6 and $10 \mathrm{~min}$.
- Supply chain: nine interviews with key informants through the supply chain, representing major processors, packers and retailers (supermarkets). Due to business practice confidentiality, these interviews explored the businesses' general drought strategies rather than referring to a specific drought event. Each interview lasted between 12 and $30 \mathrm{~min}$, with most around $20 \mathrm{~min}$.

A purposive sampling approach (Robinson, 2014; Bryman, 2016) was used to ensure access to a range of relevant stakeholders so that the perspectives of key informants from the different sectors could be researched. Participants were selected based on their ability to provide useful insights on a particular topic. Hence, the composition of the sample was more important than sample size. The purpose of the interviews was to corroborate and enrich the national analysis, so we considered that the relatively small number of interviews did not significantly affect our findings. Given the different expected drought impacts and responses, each set of interviews used a targeted semistructured interview template (see Supplementary Material), which broadly aimed to understand how they had been affected by drought; the nature of the responses they implemented and what they could have done differently. Each template was framed based on the literature review and trade magazine analysis and refined through pilot interviews with researchers who were knowledgeable on agricultural drought management. Approval of each questionnaire and interview protocol was obtained from Cranfield University's ethics committee (CURES/653/2018 and CURES/8399/3019). Each interviewee was assigned a coded identifier to ensure anonymity.

The interviews were analyzed by synthesizing and classifying the interviewee responses to make better inferences about the impacts and responses reported in the agricultural trade publications. Interview responses were analyzed using a partdeductive/part-inductive approach to thematic coding, in which the themes from the agricultural trade publications were open to the identification of new themes or sub-themes. The paper is not intended as a complete compendium of drought impacts or responses (see Rey et al., 2019), but rather a critique and illustrative summary of the different types of impacts and responses witnessed in 2018 to inform the conceptual development of a drought management framework.

\section{RESULTS}

\section{Driver-Pressure-State: The Agrometeorology of 2018}

Following an unusually cold and wet April, many parts of central England recorded less than half the average summer rainfall (Kendon et al., 2019) and many places, particularly in eastern and north-west England, broke records for low rainfall and/or high daytime temperatures in the period between May and July. June was particularly dry, with parts of central and southern England recording $<5 \mathrm{~mm}$ rainfall (Kendon et al., 2019). The combined effect of low rainfall and high temperatures created a "meteorological drought" over much of the country. By the 
end of July, the 3 months Standardized Precipitation Index (SPI3) was showing "extremely dry" conditions in most of East Anglia, parts of north-west England, south west England, west Wales and the north of Scotland (Figure 1). Some heavy downpours in late July ushered in a return to broadly average conditions in August, but in much of England, Northern Ireland and parts of Scotland, September rainfall was again below average.

Figure 2 shows the development of the PSMD at Cambridge and Blackpool during 2018. The dry period in 2018 started later than in 1976 in Cambridge but slightly earlier in Blackpool, however the PSMD increased rapidly between 15 May and 27 July in both locations due to very low rainfall (25 and $52 \mathrm{~mm}$, respectively). Although the maximum PSMD $\left(\mathrm{PSMD}_{\max }\right)$ in 2018 was lower at Blackpool $(268 \mathrm{~mm})$ than at Cambridge $(448 \mathrm{~mm})$ reflecting particularly the higher rates of evaporation in south east England, the annual exceedance probability of the $2018 \mathrm{PSMD}_{\max }$ was $2 \%$ and $4 \%$, respectively, (Knox and Hess, 2019). The summer of 2018 could therefore be considered an extreme drought in both locations.

By July, exceptionally low river flows were recorded in many catchments (CEH, 2018) although in the south and east, groundwater fed rivers were at normal levels, due to the wet winter and spring. One water company in the north-west of England planned, but did not implement, a "Temporary Use Ban" that limited domestic irrigation (United Utilities, 2018) but agriculture was exempt from formal spray irrigation restrictions. Therefore, the impact of dry weather on water resources in 2018 was not as severe as in the summer of 1976, which followed a very dry 1975 (Marsh et al., 2007).

\section{Impacts}

The national extent of dry conditions (Figure 1) and the severity (Figure 2) meant that drought impacted all three farming systems in 2018, with reported impacts in the trade magazines cuttingacross cropping and livestock sectors (Figure $\mathbf{3}$ and Supplementary Table S1). Most of the reported impacts were negative, particularly poor crop growth and development leading to reduced yields (for both food crops and grassland), and reduced livestock feed availability. Unsurprisingly there was also variability in impacts, with crops on more drought prone sandier soils being more impacted than those on more moisture-retentive clay-rich soils, and rain fed crops were impacted more than those that were irrigated. There was a small number of reported positive impacts, related to increased prices, reduced crop pests/disease pressure and improved soil conditions for farm operations. The increases in United Kingdom prices for some agricultural outputs did not result simply from the drought impacts in the United Kingdom but were also influenced by the concurrent drought in Ireland and continental north-west Europe increasing demand for livestock feed and reducing cereal production, respectively. However, reported impacts on farm income were all negative, indicating that any benefits from increased prices received on agricultural outputs were offset by reduced yields and increased costs, and leading to reported negative impacts on farmer well-being.
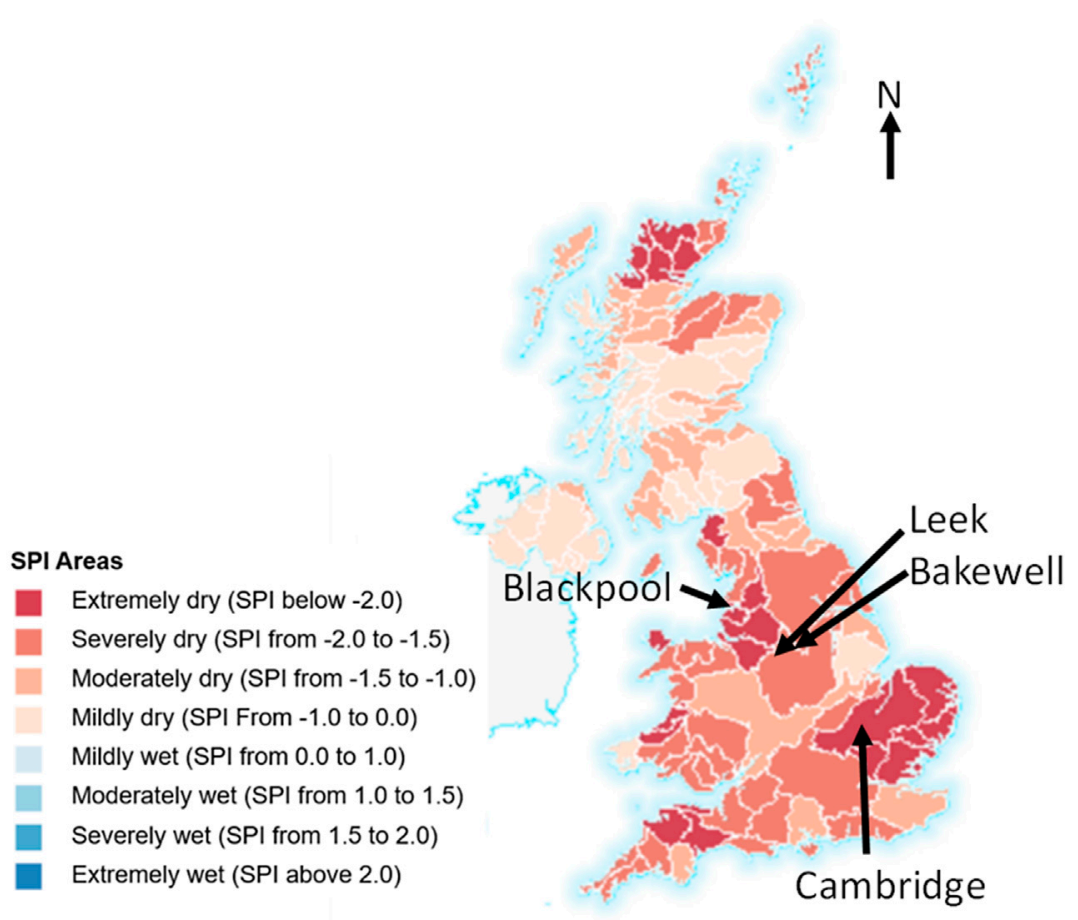

FIGURE 1 | Spatial distribution of the 3-month Standardized Precipitation Index (SPI) for river basins across the United Kingdom for the 3 month period ending in July 2018 (Source: UKCEH Drought Portal). The locations of towns mentioned in the paper are indicated. 


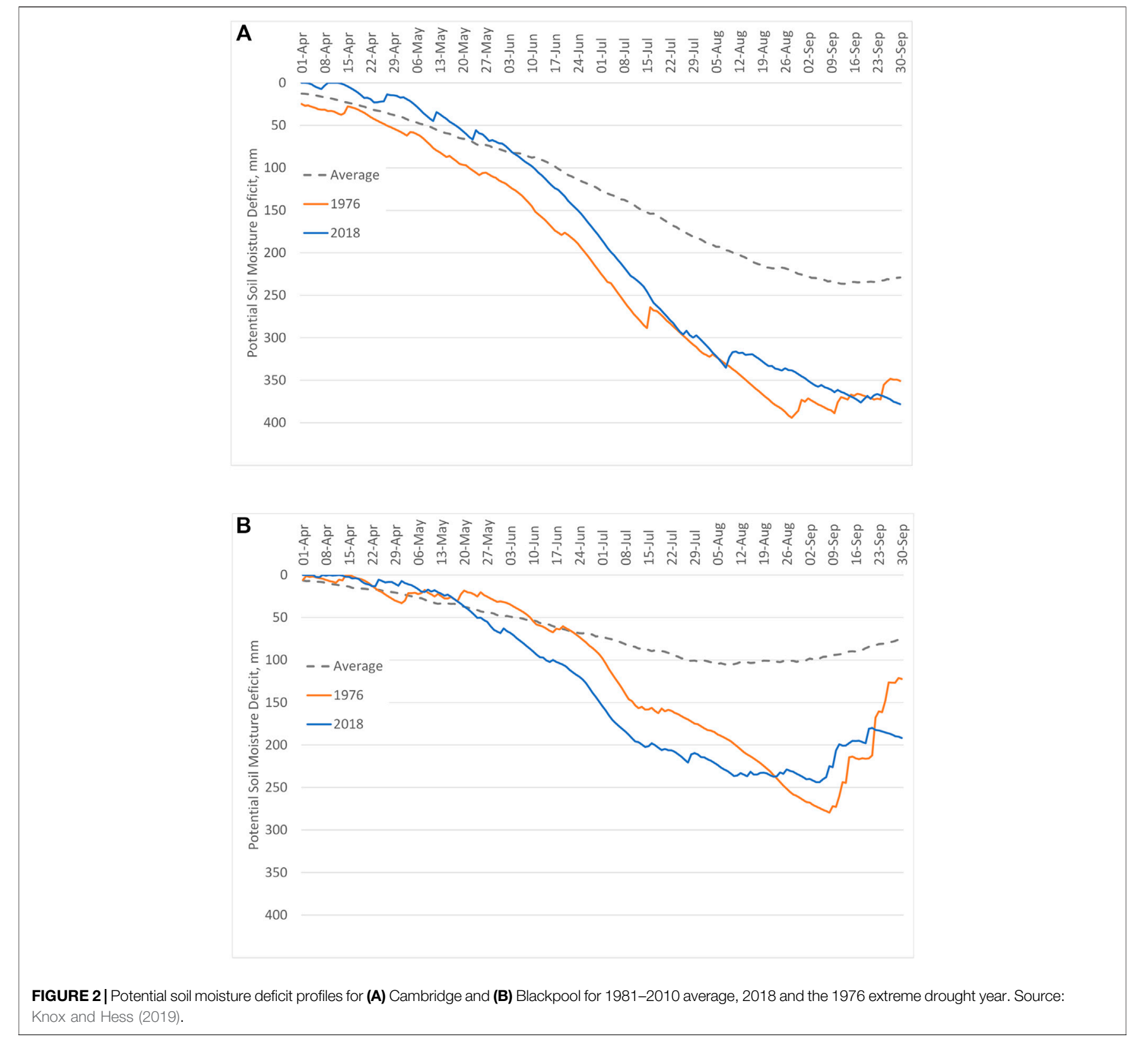

\section{Responses}

Given the spatial extent and severity of the 2018 drought, it is unsurprizing that a wide range of responses to the drought were reported in the farming press to minimize yield losses, maintain animal welfare, reduce costs and maintain cashflow. The most commonly reported responses were modifying planting and harvesting practices, feed/bedding management, selling livestock and feed purchases/sales (Figure 4), reflecting the significant impact of the drought on outdoor livestock production. Cross-sectoral industry responses to the challenges in the outdoor livestock sector were seen in arable farmers baling straw (rather than incorporating into the soil) to both support the livestock sector and to capitalize on strong growth and prices (Table 1 and Supplementary Table S2).
Growers who had access to irrigation were irrigating at peak capacity for much of the season, resulting in increased labor and energy costs. However, many growers reported that they did not have sufficient irrigation equipment and/or license capacity to meet the sustained agronomic demand over their entire cropped area, due to protracted high temperatures and ET rates. Consequently, growers had to make difficult decisions about prioritizing limited supplies of available irrigation among competing crops, or sacrificing crops entirely. Some were able to expand the capacity of their irrigation system, but there was high demand for equipment all around the country and the rest of Europe.

However, while most reported responses were on-farm, a diverse range of responses were reported from other farming 


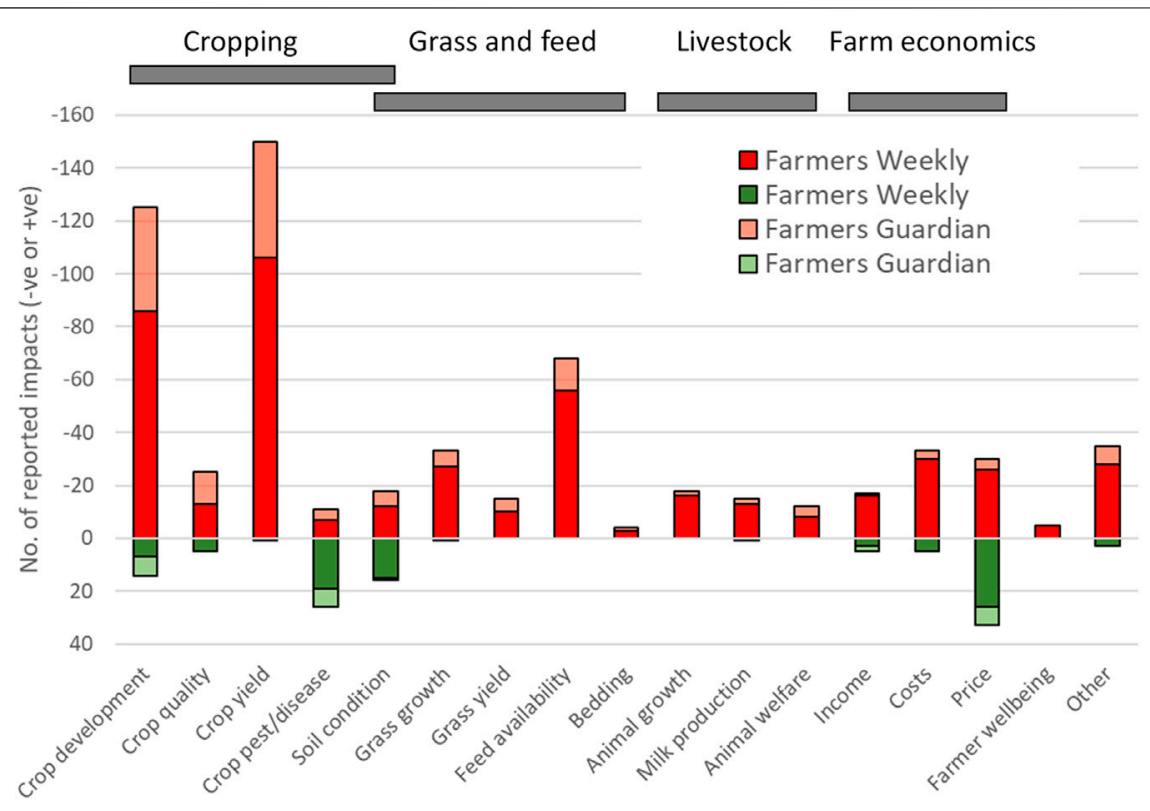

FIGURE 3 | Negative and positive drought impacts reported in Farmers Weekly and Farmers Guardian trade magazines in 2018.

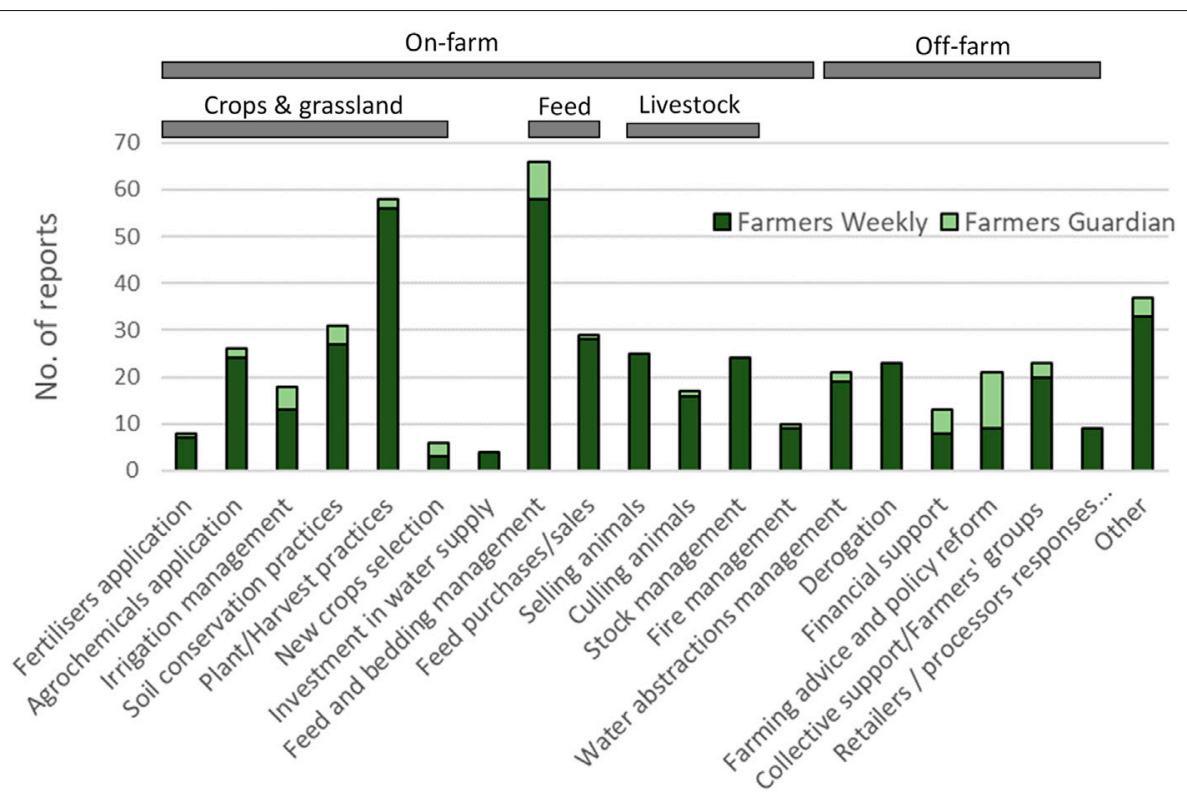

FIGURE 4 | Drought management responses reported in Farmers Weekly and Farmers Guardian trade magazines in 2018.

and non-farming actors (Figure 4, Table 1 and Supplementary

Table S2). These included actions to:

- Communicate drought management advice: from fellow farmers, the agricultural levy boards, National Farmers Union (NFU), water abstractor groups, independent and retailer agronomists
- Provide collective support: these ranged from the NFU Fodder Bank scheme and the Fodder Aid charity that sought to assist livestock farmers in procuring animal feed; the Royal Agricultural Benevolent Institution (RABI) that provided emergency financial support to struggling farmers; NFU Water Bank to help bringing together farmers who needed water with farmers that had 
TABLE 1 | Exemplar reported short-term responses to drought impacts across the United Kingdom farming sector.

\section{Sector}

On-farm (cropping)

On-farm (livestock)

Farming community

Suppliers

Government agencies

Retailers/processors

Government

\section{Short-term responses (exemplars)}

"Growers considering this route should aim to take crops [potatoes] out in the very early morning when they have had a chance to rehydrate overnight." [FG July]. "We are doing everything we can to preserve water, including irrigating at night and using boom irrigators rather than rain guns to avoid evaporation." [FG July]. "Some fields that weren't planned to be irrigated were brought under irrigation where water was available, but the cost of equipment, pipe, labor, etc. was high." [I6]

"Since there were shortages of feed all over the country I had to mix my silage straw with and feed them to my animals" [B10]. "Any animal that was not productive at this time of production was culled" [L2]. "We were using some of the winter feed in the summer" [L11]

"I received advice from a neighboring farmer" [L6]. "Support from RABI is tailored to suit individual need and helps with contributions toward domestic bills or providing emergency grants." [FG July]. "There was some temporary trading of water among growers. For example, a water transfer scheme provided a 'reserve' of water that some license holders were not using that was made available to others." [11]

"Because we regularly purchase feed from our suppliers even on a normal year, they said "you buy off us 52 weeks of the year, so you'll get yours"'” [L10]

"We are on the environmental scheme and the only help we received was that we were allowed [by Natural England] to mow early because the grasses were not growing early enough for us to feed our animals". [L4]. "The Environment Agency were proactive and gave an extra month of abstraction on winter licences (to end of March)." [12]

"British Sugar reduced the factory processing rate by $20 \%$ in the first few weeks of the season to allow the crop to stay in the ground longer and put on extra yield." [11]. "We try to work very closely with our growers. ...We don't really want to take them to court because they haven't achieved their contract, so we are not trying to beat them up over that" [SC8]. "... multiples reduced quality specification but growers felt it was too late." [12]. "we will have to go overseas, to France or wherever to increase the amount of supply we are obtaining from elsewhere." [SC1]

"Defra has announced 40 temporary prescription adjustments (TPA) to help drought-hit farmers in stewardship schemes provide extra fodder, bedding or grazing for their stock" [FW September]. "the Welsh government announced a £500,000 donation to farming charities to provide short-term support to families in Wales who are least able to meet living costs." [FW August]. "The United Kingdom is under pressure to implement a Brussels decision allowing EU member states to make early direct payments to farmers battling drought conditions." [FW August]

Note: FW, Farmers Weekly; FG, Farmers Guardian; B, Bakewell market; L, Leek market; SC, Supply chain; and the number refers to the interviewee number.

a surplus; and formal/informal water abstractor groups (which are made up of irrigation abstractors within a given catchment) who facilitated temporary trading of water among irrigators and collectively negotiated with the water regulator (Environment Agency, EA)

- Modify regulations and proscriptions: the EA worked with irrigators to provide flexibility within abstraction management enabling, for example, emergency water trades; while Natural England provided derogations on agri-environment scheme constraints to livestock farmers to increase access to grazing land

- Modify contractual terms: processors, packers and retailers reduced their stringent quality assurance standards for fresh produce to utilize as much of the harvested crop as possible; some supermarket chains relaxed their contractual requirements regarding quantities, delivery schedules and/or quality specifications (e.g., potato size requirements). Retailers started campaigns aimed at attracting customers to buy lower quality or smaller than usual fruit and vegetables (e.g., "Wonky veg")

- Provide financial support: early Common Agricultural Policy (CAP) payments by the Rural Payments Agency to ease cashflow and flexibility from financial institutions were advocated.

- Provide strategic direction: the Department for Environment, Food and Rural Affairs (Defra) held an emergency drought summit with representatives from the EA, Natural England, the Rural Payments Agency, NFU and several farming charities to seek a co-ordinated response to the emerging drought situation. However, much day-to-day direction came from the National Drought Group (formed after the 2010-2012 drought) chaired by the Environment Agency, the regulating agency for Defra.

It is not possible to say whether these measures were 'effective' or not. The average Farm Business Income in 2018/19 (covering the 2018 harvest) reduced for dairy and grazing livestock farms, due largely to higher feed costs (Defra 2019)-for example, the average incomes for grazing livestock farms fell by 39 percent for lowland farms and 42 percent for those in the Less Favored Areas (mostly uplands) demonstrating the large financial impact of the common response to maintain herds through increased supplemental feed. In contrast, the reduced crop yields on cereal and general cropping farms were mitigated by higher prices for some crops, particularly cereals, leading to increased average incomes of 8 and 22 percent, respectively (Defra 2019). However, the total number of United Kingdom farm holdings in June 2019 was 219 thousand (Defra 2020) compared to 217 thousand in 2017 (Defra 2019), suggesting that the adaptation responses had enabled most farms to survive beyond the drought.

Drought responses, both short-term coping (Table 1 and Supplementary Table S2) and longer-term adaptation strategies (Table 2 and Supplementary Table S3), were implemented across institutional scales (farms, farmer groups, farmer organisations, government agencies and policymakers) 
TABLE 2 | Exemplar reported longer-term responses to drought impacts across the farming sector.

Sector Longer-term responses

On-farm (cropping)

"Many businesses have been compromising on irrigation investment-but not anymore. We hadn't moved on, but now looking long and hard at the resilience of our business planting programmes and water resources needed to meet contracts in a drought year. 2018 was a wakeup call." [18]. "In the short term, building a reservoir is not a quick solution, but we are encouraging farmers to ... look at longer term resilience options such as a storage reservoirs." [FG April]. "... he has a strategy of early drilling and high seed rates to prepare for the dry spring and summer which he knows will inevitably come" [FW September]. "With this year's drought there's also increasing evidence to show that shelter belts and planting trees in the right place will reduce water loss from the soil, making more available for the crop rather than evaporating." [FW October]

On-farm (livestock) "We didn't sell our animals because we needed the parents with good quality traits to be around during subsequent production cycle". L6]. "This has led Mr Gribble to make another difficult decision: to get a part-time job" [FW, August]. "In a year of challenging weather conditions which have led widespread grass silage shortages, maximizing the value of alternatives like maize could become increasingly important." [FG August]. "I constructed a borehole last year which will serve as alternative source of water in time of drought" [B9]

Farming community "In the short term... we are encouraging farmers to consider water abstraction groups." [FG April]. "Lincolnshire farmer and Forage Aid founder Andrew Ward said he hadn't baled straw for many years but was doing so this year, with straw destined for Cumbria and other areas to help livestock farmers." [FW August]. "If the farmer group call saying they are going to be short, we know that they will try to fill that by anyone in their group that has a surplus, or other potatoes somewhere else that they can buy for us" [SC2]

Suppliers

Government agencies None reported

"The Environment Agency response was generally too slow to cope with emerging issues, although local staff ... provided excellent support to growers" [19] "The Environment Agency should allow more flexibility in licensing (e.g., changing abstraction points), earlier. There was a feeling that in 2018 the response was too late". [11]

Retailers/processors "... we have recently started selling reduced price 'wonky' veg and these have been performing very well, so this indicates a growing customer acceptance of such produce." [SC5]. "We have about 10 contracts but they are what we call our growers groups, and within those growers groups there could be 20 growers." [SC2]. "A lot of our farmers have been with us for many years, 2nd or 3rd generation in some cases. We ...work with a farmer in the relationship so we are looking at improving the technical competence of the growers" [SC2]. "water security is definitely one of the attributes we look for in a grower: on farm reservoirs, good irrigation appliances ... they are key part of growers select" [SC4]. "The big thing each time you have a weather event like that, the whole supply chain learn from that, and those other things like more geographical spread, more CAPEX, better training of the growers" [SC9]

Government

"... need to continue to foster multi sector collaboration and start some local catchment scale interventions". [19]. "Within our grower base we are encouraging farms to be self-sufficient on water, so investment in on-farm reservoirs. Something we need to call for more help from the government in terms of tax break, capital release, easier planning ... " [SC4]

Note: FW, Farmers Weekly; FG, Farmers Guardian; B, Bakewell market; L, Leek market; SC, Supply chain and the number refers to the interviewee number.

and through the supply chain (including processers, retailers and consumers), reflecting the complex interactions between Drivers, Pressures, States, Impacts and Response (DPSIR) within the food system (Figure 5). Each of the elements in the DPSIR framework in Figure $\mathbf{5}$ were also classified according to whether they were related to farming, water resources, climate, markets or policy/ regulation aspects. It is evident that the impacts of drought are not solely due to climate pressures within the United Kingdom, while the responses are not solely agricultural.

Consequently, Figure 5 shows that agricultural drought resilience cannot be considered just at the farm-scale, but has to include spatial, governance and supply-chain scales. Drought can be a large-scale regional phenomenon that can cross national boundaries, magnifying the systemic complexity of impacts and responses. The 2018 drought affected much of central and northern Europe (Buras et al., 2020), causing yield reductions of up to $50 \%$ for the main crops (Toreti et al., 2019). This led to concerns regarding the availability and quality of agricultural commodities; competition for limited market availability of key equipment (e.g., new and second-hand irrigation equipment); and unintended consequences of other national drought responses on market demand and prices (e.g., Irish transport subsidies for fodder purchases in the United Kingdom).

\section{DISCUSSION}

In their resilience trinity, Weise et al. (2020) identify two decision contexts of relevance to drought management in agriculture-reactive decisions where the loss of the desired functions (e.g., food production) due to a current threat (e.g., drought) is imminent or already happening; and adjustive decision contexts where the desired functions are threatened by future threats (Ault, 2020), but not yet to a critical level. In such a decision context, concerns about losses from future uncertain drought events exist, but initiatives and incentives to adjust current management practices to increase longer-term drought resilience might be neglected (Boltz et al., 2019), slow or even fail because of the lower perceived urgency for actions (Weise et al., 2020).

This potential dichotomy is clearly evident in Figure 4 in which a wide range of drought responses initiated or advocated by a diversity of actors were identified. The reported drought responses were dominated by actions that focused on shortterm actions (Table 1 and Supplementary Table S2) to cope with the drought (e.g., crop management; purchasing additional feed) or short-medium term actions (Table 2 and Supplementary Table S3) that enhanced the recovery from the drought (e.g., maintaining current livestock herd genetics), but which 


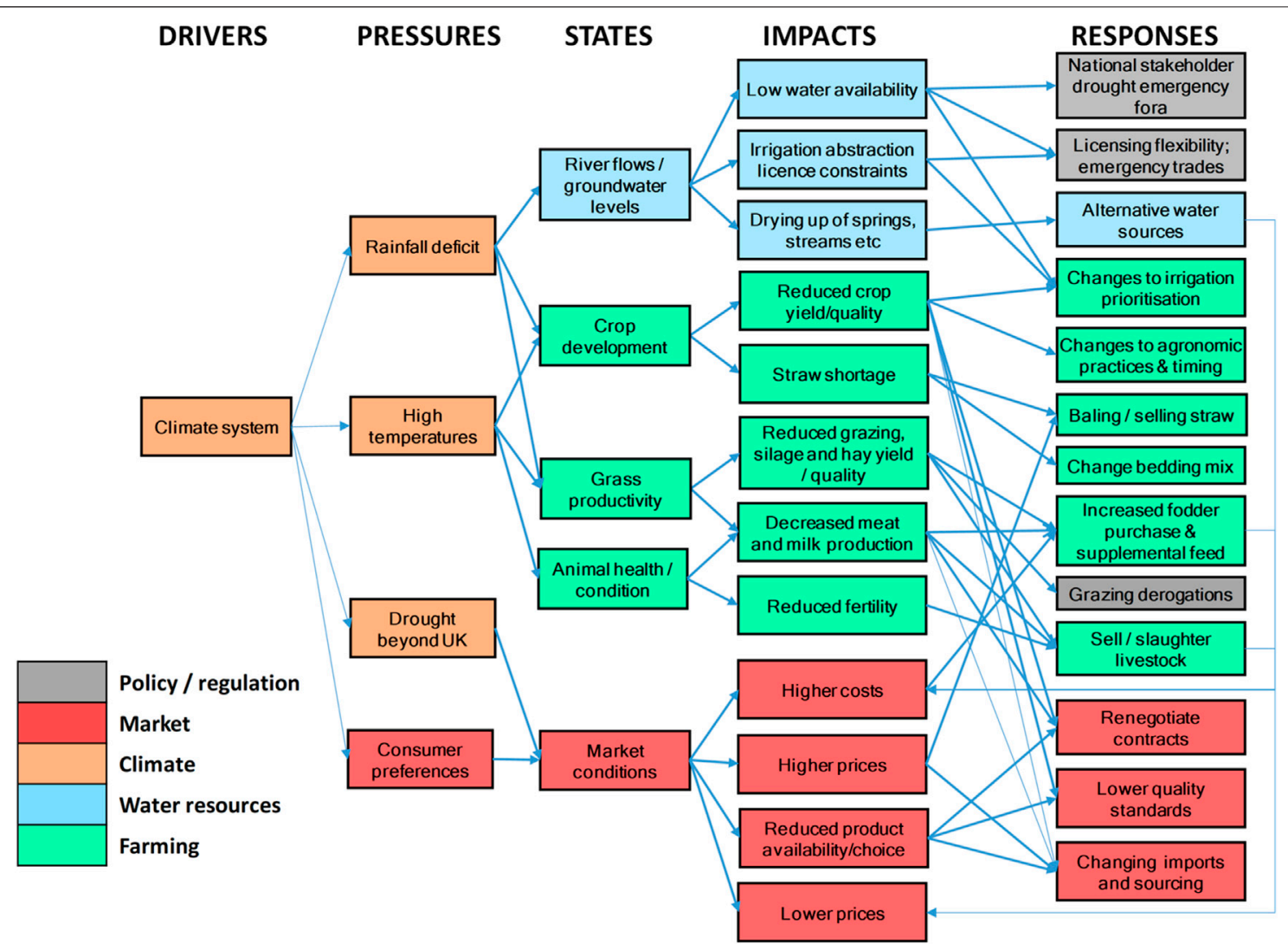

FIGURE 5 | Simplified Driver-Pressure-State-Impact-Responses schematic for agriculture, showing how drought impacts and responses are interconnected to a range of drought pressures both from within and outside the United Kingdom.

contributed to little anticipated increase in resilience to future drought events. This evidence from the United Kingdom corroborates a more widely accepted approach to the management of drought risk that is reactive and crisis-driven (Cruz et al., 2018; Hess et al., 2020), with potentially negative consequences for health and social outcomes (Edwards et al., 2018).

There were fewer reported examples of longer-term adaptive responses within the farming literature and interviews, which broadly separated into four groups of actions: 1) the development or adoption of more drought-tolerant crop cultivars or grasses to reduce drought sensitivity; 2) increased farmer collaboration to increase collective influence; 3) investment in on-farm water supplies to reduce vulnerability to hydrological drought; and 4) risk-sharing through geographically dispersed production and sourcing to reduce drought exposure. This is consistent with earlier evidence of actions to increase drought resilience in irrigated agriculture (Rey et al., 2016; Rey et al., 2019), and outdoor livestock (Rey et al., 2019; Salmoral et al., 2020a). In contrast, Wreford and Adger (2010) suggested that a progressive reduction in the impacts of droughts and heatwaves on nationalscale production of three out of five crop commodities and two out of four livestock categories investigated, was indicative of the United Kingdom agricultural sector being relatively well adapted to the current climate. However, this analysis did not account for differences in drought severity and extent, or the spatial coincidence of drought events and production areas.

Adaptive strategies that increased resilience within the farming system, through building diversity (Allison and Hobbs, 2004), redundancy (D'Odorico et al., 2010) or headroom (Cabel and Oelofse, 2012), carry costs. For those strategies seen within the farming literature and interviews, these costs which can represent barriers to change include capital investment costs (eg a farm irrigation reservoir, drinking water infrastructure), operational costs (e.g., soil management; feed mix changes; management overheads), profits foregone (e.g., reduced cropping or grazing areas; reduced livestock numbers) and opportunity costs (Abson et al., 2013) (e.g., reservoir storage that is not used in most years; reduced yields of drought-tolerant cultivars; reserved grazing; increased stored/conserved feed) that must be justified by the penalties avoided in occasional drought years. The willingness or ability to incur these additional costs can be limitted by farm business characteristics, risk attitudes (Knox et al., 2010; Rial-Lovera et al., 2017) and drivers of economic efficiencies. The limiting conditions created by the combination of highly competitive operational environments and the low profitability of some farming systems (particularly upland livestock) results infarm business decision-making often focuses on enhancing the economic efficiency of production, 
TABLE 3 | Mapping resilience actions by different stakeholders to increasing the five capitals.

\begin{tabular}{|c|c|c|c|}
\hline Capital-type & Resilience actions & By whom & Benefits \\
\hline \multirow[t]{5}{*}{ Natural } & Soil organic matter improvement & Farmer & Improved soil structure; higher water holding capacity \\
\hline & Shelter belts, tree planting & Farmer & Shading for livestock; reduced crop evapotranspiration \\
\hline & Genetic improvement & $\begin{array}{l}\text { Farmers, crop breeders, agri-technology } \\
\text { providers }\end{array}$ & Improved drought tolerance \\
\hline & Regulatory flexibility & Government, regulators & Increased short-term access to grazing and water \\
\hline & Geographic spread in purchases & Processors, retailers & Reduced drought risk to supply \\
\hline \multirow[t]{4}{*}{ Social } & Multi-sectoral collaboration & $\begin{array}{l}\text { Farmers unions; water abstractor } \\
\text { groups; Co-operatives }\end{array}$ & $\begin{array}{l}\text { Increased access to knowledge and support; sharing/ } \\
\text { trading to meet shortfalls }\end{array}$ \\
\hline & Support networks & Charities, farmers & Mental health, support \\
\hline & Communication and collective negotiation & $\begin{array}{l}\text { Farmers, water abstractor groups, } \\
\text { regulator }\end{array}$ & Increased trust \\
\hline & $\begin{array}{l}\text { Developing established business relationships and } \\
\text { supply chain collaboration }\end{array}$ & $\begin{array}{l}\text { Farmers, farmer groups, processors, } \\
\text { retailers }\end{array}$ & Increased trust and support \\
\hline \multirow[t]{3}{*}{ Human } & Consumer awareness & Retailers; farmers unions, NGOs & $\begin{array}{l}\text { Increased acceptability of 'imperfect' fruit and } \\
\text { vegetables }\end{array}$ \\
\hline & Farmer training; advice & $\begin{array}{l}\text { Agronomists; levy boards; processors } \\
\text { and retailers }\end{array}$ & Improved agricultural practice \\
\hline & Forecasting and early warning & $\begin{array}{l}\text { Scientists, data providers, environmen- } \\
\text { tal regulator }\end{array}$ & Improved decision making \\
\hline \multirow[t]{3}{*}{ Manufactured } & $\begin{array}{l}\text { On-farm reservoirs and alternative water supply (e.g., } \\
\text { borehole) }\end{array}$ & Farmer/environmental regulator & Security of supply \\
\hline & Equipment redundancy & Farmer & Increased capacity during extreme event \\
\hline & Crop storage facilities & Farmer groups; processors; packers & Smooth supply fluctuation \\
\hline \multirow[t]{5}{*}{ Financial } & Diversification & Farmer & Reduced income volatility \\
\hline & Insurance & Farmer; financial institution & Reduced financial losses \\
\hline & Agricultural support payments (PPGs, PES) & Government & Targeted financial support \\
\hline & Contractual flexibility (quality assurance, prices) & Processors, retailers & Protected farm income; reduced wastage \\
\hline & Investment support (tax incentives; subsidies) & Government & Increased capital investment \\
\hline
\end{tabular}

through utilizing any 'spare' resources and minimizing opportunity costs, thereby diminishing system redundancy and eroding resilience (Hess et al., 2020).

With drought events projected to become more frequent and severe due to climate change (Grillakis, 2019), agriculture needs longer-term planning and investment to build resilience that is guided by, and supports, short-term emergency responses, effective adaptation to repeated shocks and appropriate preparation for unexpected extreme events (Harris et al., 2020). However, the wider lack of long-term planning and investment in drought management in agriculture (evident in Figure 4, Table 2 and Supplementary Table S3) despite drought being a familiar and relatively frequent stressor, demonstrates that transitioning from short-term reactive coping responses to longer-term and anticipatory responses is a much more entrenched and longer-term challenge for the industry. Adaptations undertaken by different actors will need to work in cohort to increase the resilience of the system as a whole., Retailers (and processors) have a potentially important role to play in enabling change and promoting resilience in the supply chain (MacFayden et al., 2015), by providing farmers and grower groups with agronomic support and longer-term contractual relationships that can provide the confidence for long-term business investments (such as for farm reservoirs).

It is common for resilience theory and sustainability to be considered as complementary approaches (Redman, 2014), although they are independent concepts (Derissen et al., 2011). Nevertheless, while the property of resilience should not be confused with the positive normative connotations of sustainability (Derissen et al., 2011; Kreuger et al., 2020), the five capitals model (Viederman, 1994; Forum for the Future, undated, 2018) forms a framework for sustainability and can support long-term planning for resilience (Harris et al., 2020). Table 3 characterizes the resilience actions identified within the farming literature and interviews (Figure 4, Tables 1, 2) according to the capitals they enhance, but recognizes that actors in the food production chain can influence capitals at different governance scales (Figure 6).

Natural capital represents the ecosystems/assets from which there is a flow of services and/or products, and is represented by the land, soil and water on which crops, grass and livestock production are dependent. Given the central role of rainfall and water in agriculture (as shown within the DPSIR schematic-Figure 5), improving natural capital through improved soil and land management to increase soil water storage and availability is a foundation of drought resilience (Rockstrom, 2003; Vogel et al., 2012; Rial-Lovera et al., 2017). For irrigated agriculture, this also needs to be augmented by an abstraction management regime that is sufficiently dynamic and flexible to create market or regulatory signals that promote an efficient allocation and use of water that balances the needs of the environment with abstractors (Ofwat and Environment Agency, 2015).

Human capital is the representation of people's health, knowledge, skills and motivation, which are all needed for productive work and which are important for resilience 


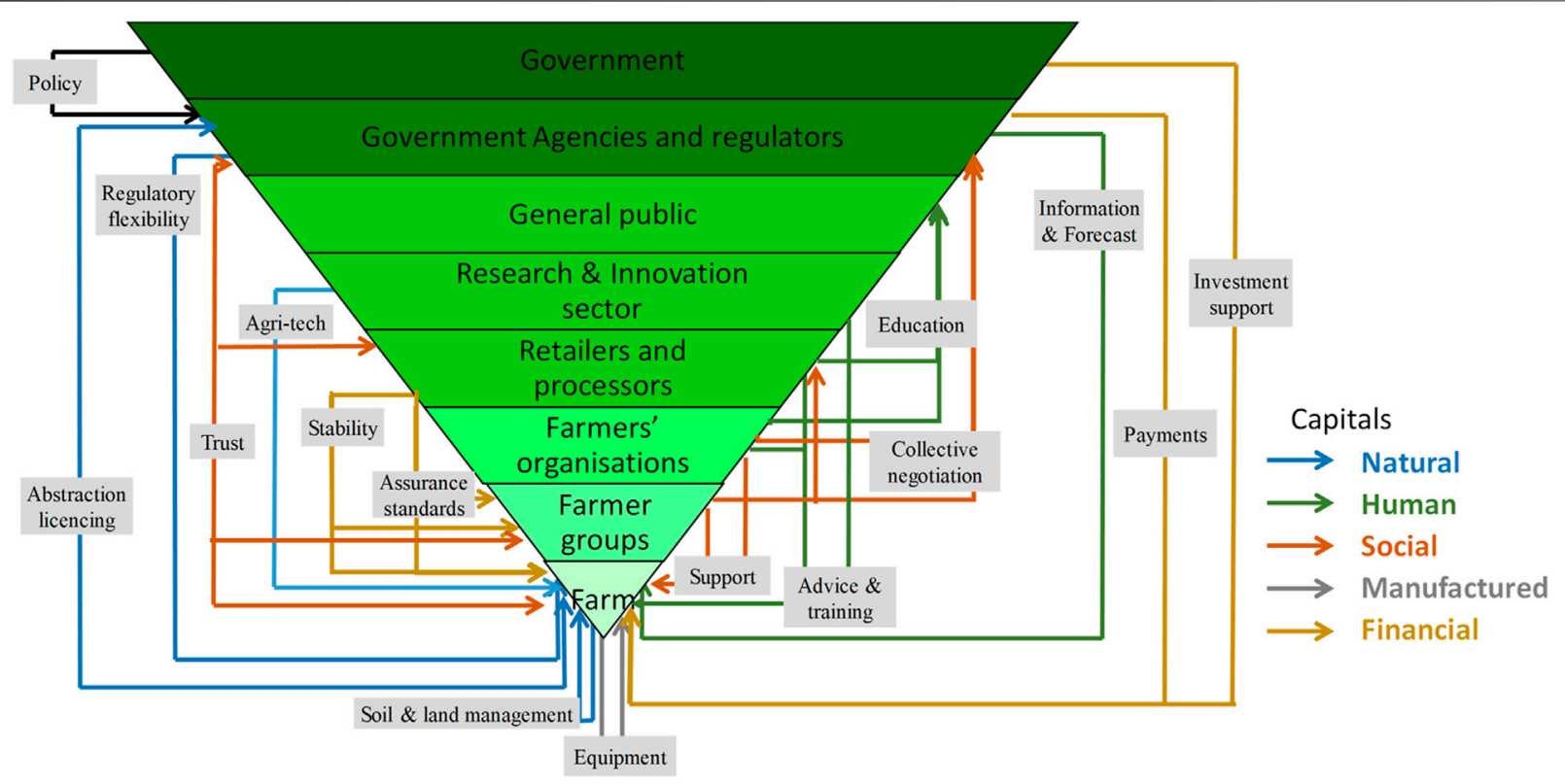

FIGURE 6 | Drought management framework for agriculture, showing the multiple levels of institutions and the relationships between broad actions and capitals.

(Himanen et al., 2016). Being able to appraise and appropriately implement adaptive responses requires improved knowledge and capacity throughout the production system from farmers and agronomists to retailers and consumers (Figure 6); and into the system from data and service providers (Hannaford et al., 2019; Haro-Monteagudo et al., 2019; Prudhomme et al., 2019) and agritechnologists (Lowry et al., 2019). While farmers can rely on their own human capital, it can be strongly enhanced by connectedness to shared resources via social capital (Darnhofer, 2014). Social capital is the sum of the institutions and associated networks that help maintain and develop human capital in partnership with others. This includes families, communities, businesses, trade unions, educational establishments, and voluntary organisations. The importance of social capital for enhancing drought resilience is evidenced from the range of actions (Table 2 and 3) across governance levels (Figure 6) that enhance knowledge development (e.g., provision of agronomic advice), collaboration (e.g., development of water abstractor groups, Leathes et al., 2008), trust, negotiating power (producer groups, water abstractor groups, Whaley and Weatherhead, 2015), risk-sharing (co-operatives, farmer producer groups) and risk balancing (e.g., supplier networks, Hess and Sutcliffe, 2018).

Financial capital (e.g., shares, bonds, cash) enables the other types of capital to be owned and traded. To date, public financial support to agriculture, for example through the European Union's Common Agricultural Policy (CAP), has generally not targeted supporting adaptive changes, with agri-environment payments based on profits-foregone which provides limited incentive for adoption. However a movement toward targeted payment for public goods (Bateman and Balmford, 2018) and payment for ecosystem services (Waylen and Martin-Ortega,
2018) provides the opportunity for a win-win in which enhanced financial support for critical public goods such as carbon sequestration and flood regulation can also help enable agricultural measures that deliver increased drought resilience (Salmoral et al., 2020a). Finally, manufactured (or built) capital is the material goods or fixed assets contributing to the production process, but which are not part of the output, e.g., tools, machines and buildings. Being able to invest in on-farm water storage, irrigation equipment, climate-adapted buildings and storage facilities provides robustness to reduced rainfall, water availability and food production. However, it also requires access to some or all of the other "capitals"; to human capital (for the knowledge to plan, design, and implement), social capital (to facilitate business relationships that provide some degree of financial stability), financial capital (to finance investment), and natural capital (to access, for example, water).

Our drought management pyramid (Figure 6) provides an evidence-based and transferable framework to transition from coping (short term) to adapting (long-term) strategies to increase resilience to future droughts by better horizontal (farms, farmer groups, agricultural sub-sectors, agricultural sector) and vertical (supply chain, regulator) integration. This requires increased and improved collaboration and engagement across spatial, governance and supply-chain scales (Figure 6) that develop human capital (knowledge) and social capital (trust). Many relevant adaptive actions are initiated reactively at short-notice as drought impacts manifested, as seen in 2018. The challenge for the agricultural industry, supply chain, regulator and government moving forward is to convert this ad hoc reactive learning into anticipatory longer-term measures that support drought resilience, food security and rural livelihoods while protecting the environment. 


\section{CONCLUSION}

Agriculture has always been exposed to climate extremes, whether to agricultural and/or hydrological droughts, and this situation is unlikely to change (Grillakis, 2019). The 2018 drought in the United Kingdom demonstrated how agricultural systems in humid temperate regions are vulnerable to drought, with drought impacts reported across rainfed and irrigated production systems and in livestock, arable and horticultural farming. Despite a number of drought events over the past 40 years, the diverse range of drought responses were mostly focused on short-term actions to cope with, or enhance the recovery from, drought. This arises, in part, because adaptive strategies that increase resilience, through building diversity, redundancy or headroom, carry costs which many businesses are unwilling or unable to carry or which are utilized to enhance economic efficiency given competitive operational environments and low profitability. Transition from coping (short-term and reactive) to adapting (longer-term and anticipatory) strategies to increase agricultural resilience to future droughts requires improved collaboration across spatial, governance and supply-chain scales that develop human capital (knowledge) and social capital (trust). Industry, supply chain, regulators and governments need to work together to use the learning from recent droughts to develop a drought strategy that improves drought resilience, food security and rural livelihoods while protecting the needs of the environment.

\section{DATA AVAILABILITY STATEMENT}

The datasets presented in this study can be found in online repositories. The names of the repository/repositories and accession number(s) can be found below: United Kingdom Data Service [https://reshare.ukdataservice.ac.uk/854457/ and https://reshare.ukdataservice.ac.uk/853167/] and Cranfield Online Research Data [https://doi.org/10.17862/cranfield.rd. 13259291].

\section{ETHICS STATEMENT}

The studies involving human participants were reviewed and approved by the Cranfield University Research Ethics System.

\section{REFERENCES}

ABC (2020). Audited circulation certificates. Available at: https://www.abc.org.uk/ Certificates/49664504.pdfhttps://www.abc.org.uk/Certificates/49664449.pdf (Accessed May 1, 2020).

Abson, D. J., Fraser, E. D. G., and Benton, T. G. (2013). Landscape diversity and the resilience of agricultural returns: a portfolio analysis of land-use patterns and economic returns from lowland agriculture. Agric. Food Secur. 2, 2. doi:10.1186/ 2048-7010-2-2

Allison, H. E., and Hobbs, R. J. (2004). 'Resilience, adaptive capacity, and the "lockin trap" of the Western. Australian agricultural region'. Ecol. Soc. 9 (1), 3. 10. 5751/ES-00641-090103
The participants provided their written informed consent to participate in this study.

\section{AUTHOR CONTRIBUTIONS}

Conceptualization, IH, TH, and JK; Methodology, IH; Formal Analysis, IH; Investigation, TH and DR; Data Curation, DR and TH; Writing-Original Draft Preparation, IH; Writing-Review and Editing, IH, TH, DR, and JK; Visualization, IH; Project Administration, IH; Funding Acquisition, IH, JK, TH, and DR.

\section{FUNDING}

This research was funded by the United Kingdom Droughts and Water Scarcity (D\&WS) program, a Natural Environment Research Council program in collaboration with other United Kingdom Research Councils (Economic and Social Research Council, Engineering and Physical Sciences Research Council, Biotechnology and Biological Sciences Research Council and Arts and Humanities Research Council), grant number NE/L010070/1.

\section{ACKNOWLEDGMENTS}

We thank the many interviewees who freely gave of their time. We acknowledge Benjamin Ababio (Cranfield University) who conducted the interviews at Leek and Bakewell livestock markets, Ivan Grove (Harper Adams University) who assisted with the grower interviews, Gloria Salmoral (Cranfield University), Benjamin Ababio and Matthew Holman who reviewed the farmer periodicals and Nevil Quinn (University of the West of England- ENDOWS agricultural workstream co-ordinator). We acknowledge the Environment Agency for access to the 2018 meteorological data used to derive potential soil moisture deficit.

\section{SUPPLEMENTARY MATERIAL}

The Supplementary Material for this article can be found online at: https://www.frontiersin.org/articles/10.3389/fenvs.2020.589871/ full\#supplementary-material.

Anglian Water and University of Cambridge (2013). Water, water everywhere? encouraging collaborating and building partnerships. Available at: https://www. cisl.cam.ac.uk/business-action/business-nature/natural-capital-impact-group/ pdfs/water-water-everywhere-scroll.pdf (Accessed November 4, 2020).

Ault, T. R. (2020). On the essentials of drought in a changing climate. Science. 368 (6488), 256-260. doi:10.1126/science.aaz5492

Azadi, H., Keramati, P., Taheri, F., Rafiaani, P., Teklemariam, D., Gebrehiwot, K., et al. (2018). Agricultural land conversion: reviewing drought impacts and coping strategies. Intern J Disaster Risk Reduction 31, 184-195. doi:10.1016/j. ijdrr.2018.05.003

Bachmair, S., Kohn, I., and Stahl, K. (2015). Exploring the link between drought indicators and impacts. Nat. Hazards Earth Syst. Sci. 15 (6), 1381-1397. doi:10. 5194/nhess-15-1381-2015 
Barker, L. J., Hannaford, J., Chiverton, A., and Svensson, C. (2016). From meteorological to hydrological drought using standardised indicators. Hydrol. Earth Syst. Sci. 20 (6), 2483-2505. doi:10.5194/hess-20-2483-2016

Bateman, I. J., and Balmford, B. (2018). Public funding for public goods: a postBrexit perspective on principles for agricultural policy. Land Use Pol. 79, 293-300. doi:10.1016/j.landusepol.2018.08.022

Boltz, F., Poff, N. L., Folke, C., Kete, N., Brown, C. M., Freeman, S. S. G., et al. (2019). Water is a master variable: solving for resilience in the modern era. Water Security. 8, 100048. doi:10.1016/j.wasec.2019.100048

Bryant, A. (2014). "The grounded theory method," in The oxford handbook of qualitative research. Editor P. Leavy (Oxford, United Kingdom: Oxford University Press), 115-136.

Bryman, A. (2016). Social research methods. 5th edn. Oxford, United Kingdom: Oxford University Press, 784.

Buras, A., Rammig, A., and Zang, C. S. (2020). Quantifying impacts of the 2018 drought on European ecosystems in comparison to 2003. Biogeosci. 17 (6), 1655-1672. doi:10.5194/bg-17-1655-2020

Cabel, J. F., and Oelofse, M. (2012). An indicator framework for assessing agroecosystem resilience. Ecol. Soc. 17 (1), 18. doi:10.5751/ES-04666-170118

CEH (2018). UK hydrological status update-early August 2018. Available at: https://www.ceh.ac.uk/news-and-media/blogs/uk-hydrological-status-updateearly-august-2018 (Accessed April 6, 2020).

Chung, S. O., Rodriguez-Diaz, J. A., Weatherhead, E. K., and Knox, J. W. (2011). Climate change impacts on water for irrigating paddy rice in South Korea. Irrigat. Drain. 60, 263-273. 10.1002/ird.559

Cruz, G., Baethgen, W., Bartaburu, D., Bidegain, M., Giménez, A., Methol, M., et al. (2018). Thirty years of multilevel processes for adaptation of livestock production to droughts in Uruguay. Weather Clim. Soc. 10, 59-74. doi:10. 1175/wcas-d-16-0133.1

Darnhofer, I. (2014). Resilience and why it matters for farm management. Eur. Rev. Agric. Econ. 41, 461-484. doi:10.1093/erae/jbu012

Defra (2018). Agriculture in the United Kingdom 2017. Available at: https://assets. publishing.service.gov.uk/government/uploads/system/uploads/attachment_ data/file/741062/AUK-2017-18sep18.pdf (Accessed June 15, 2020).

Defra (2019). Farm business income by type of farm in England, 2018/19. Available at: https://assets.publishing.service.gov.uk/government/uploads/system/uploads/ attachment_data/file/847722/fbs-businessincome-statsnotice-21nov19.pdf (Accessed December 16, 2020).

Defra (2020). Agriculture in the UK 2018. in food and rural Affairs. Available at: https://assets.publishing.service.gov.uk/government/uploads/system/uploads/ attachment_data/file/904024/AUK_2019_27July2020.pdf (Accessed June 25, 2020).

Derissen, S., Quaas, M. F., and Baumgartner, S. (2011). The relationship between resilience and sustainability of ecological-economic systems. Ecol. Econ. 70 (6), 1121-1128. doi:10.1016/j.ecolecon.2011.01.003

D’Odorico, P., Laio, F., and Ridolfi, L. (2010). Does globalization of water reduce societal resilience to drought? Geophys. Res. Lett. 37 (13), 1-5. doi:10.1029/ 2010GL043167

Edwards, B., Gray, M., and Hunter, B. H. (2018). The social and economic impacts of drought. Aust. J. Soc. Issues. 54, 22-31. doi:10.1002/ajs4.52

FAO (2017). Droughts and agriculture; food and agriculture organization: rome, Italy. Available at: http://www.fao.org/3/a-i7378e.pdf (Accessed May 1, 2020).

Forum for the Future, updated (2018). The five capitals model-a framework for sustainability. Available at: https://www.forumforthefuture.org/Handlers/ Download.ashx?IDMF=8cdb0889-fa4a-4038-9e04-b6aefefe65a9.

Grillakis, M. G. (2019). Increase in severe and extreme soil moisture droughts for Europe under climate change. Sci. Total Environ. 660, 1245-1255. doi:10.1016/j. scitotenv.2019.01.001

Hannaford, J., Collins, K., Haines, S., and Barker, L. J. (2019). Enhancing drought monitoring and early warning for the United Kingdom through stakeholder coinquiries. Wea. Clim. Soc. 11 (1), 49-63. doi:10.1175/WCAS-D-18-0042.1

Haro-Monteagudo, D., Daccache, A., and Knox, J. W. (2017). Exploring the utility of drought and water scarcity indicators to assess climate risks to agricultural productivity in a humid climate. Nord. Hydrol. 49 (2), 539-551. doi:10.2166/nh.2017.010

Haro-Monteagudo, D., Knox, J. W., and Holman, I. P. (2019). D-Risk: a decisionsupport webtool for improving drought risk management in irrigated agriculture. Comput. Electron. Agric. 162, 855-858. doi:10.1016/j.compag.2019.05.029
Harris, J. A., Denyer, D., Harwood, S., Braithwaite, G., Jude, S., and Jeffrey, P. (2020). Time to invest in global resilience. Nature. 583, 30. doi:10.1038/d41586020-01951-z

Hess, T. M., Knox, J. W., Holman, I. P., and Sutcliffe, C. (2020). Resilience of primary food production to a changing climate: on-farm responses to waterrelated risks. Water. 12, 2155. doi:10.3390/w12082155

Hess, T. M., and Knox, J. W. (2013). Water savings in irrigated agriculture: a framework for assessing technology and management options to reduce water losses. Outlook Agric. 42 (2), 85-91. doi:10.5367/oa.2013.0130

Hess, T. M., and Sutcliffe, C. (2018). The exposure of a fresh fruit and vegetable supply chain to global water-related risks. Water Int. 43 (6), 746-761. doi:10. 1080/02508060.2018.1515569

Himanen, S. J., Rikkonen, P., and Kahiluoto, H. (2016). Codesigning a resilient food system. Ecol. Soc. p21 (4), 41. doi:10.5751/ES-08878-210441

Hopkins, A., and Del Prado, A. (2007). Implications of climate change for grassland in Europe: impacts, adaptations and mitigation options: a review. Grass Forage Sci. 62, 118-126. 10.1111/j.1365-2494.2007.00575.x

Kendon, M., McCarthy, M., Jevrejeva, S., Matthews, A., and Legg, T. (2019). State of the United Kingdom climate 2018. Int. J. Climatol. 39, 1-55. doi:10.1002/joc. 6213

Knox, J., Morris, J., and Hess, T. (2010). Identifying future risks to United Kingdom agricultural crop production: putting climate change in context. Outlook Agric. 39 (4), 249-256. 10.5367/oa.2010.0016

Knox, J. W., and Hess, T. M. (2019). Technical report for the Environment Agency. High level review of the Optimum Water Use methodology for agriculture following the 2018 drought tin England. Available at: https://dspace.lib. cranfield.ac.uk/handle/1826/14122 (Accessed July 21, 2020).

Knox, J. W., Kay, M. G., Holman, I. P., and Hess, T. M. (2020). Irrigation water strategy for UK agriculture and horticulture. Available at http://www.ukia.org/ pdfs/irrigation-strategy-2020.pdf (Accessed January 4, 2021).

Knox, J. W., Weatherhead, E. K., and Bradley, R. I. (1996). Mapping the spatial distribution of volumetric irrigation water requirements for maincrop potatoes in England and Wales. Agric Water Manage. 31(1-2), 1-15. doi:10.1016/03783774(96)01238-3

Kreuger, E. H., Borchardt, D., Jawitz, J. W., and Rao, P. S. C. (2020). Balancing security, resilience, and sustainability of urban water supply systems in a desirable operating space. Environ. Res. Lett. 15, 035007. doi:10.1088/17489326/ab6c2d

Kuwayama, Y., Thompson, A., Bernknopf, R., Zaitchik, B., and Vail, P. (2019). Estimating the impact of drought on agriculture using the US drought monitor. Am. J. Agric. Econ. 101 (1), 193-210. doi:10.1093/ajae/aay037

Lange, B., Holman, I., and Bloomfield, J. P. (2017). A framework for a joint hydrometeorological-social analysis of drought. Sci. Total Environ. 578, 297-306. doi:10.1016/j.scitotenv.2016.10.145

Leathes, W., Knox, J. W., Kay, M. G., Trawick, P., and Rodriguez-Diaz, J. A. (2008). Developing United Kingdom farmers' institutional capacity to defend their water rights and effectively manage limited water resources. Irrigat. Drain. 57 (3), 322-331. 10.1002/ird.436

Lowry, G. V., Avellan, A., and Gilbertson, L. M. (2019). Opportunities and challenges for nanotechnology in the agri-tech revolution. Nat. Nanotechnol. 14 (6), 517-522. doi:10.1038/s41565-019-0461-7

Lu, Y. J., Cai, H. J., Jiang, T. T., Sun, S. K., Wang, Y. B., Zhao, J. F., et al. (2019). Assessment of global drought propensity and its impacts on agricultural water use in future climate scenarios. Agric. For. Meteorol. 278, 107623. doi:10.1016/j. agrformet.2019.107623

Macfadyen, S., Tylianakis, J. M., Letourneau, D. K., Benton, T. G., Tittonell, P., Perring, M. P., et al. (2015). The role of food retailers in improving resilience in global food supply. Global Food Secur. 7 (2015), 1-8. doi:10.1016/j.gfs.2016. 01.001

Marsh, T., Cole, G., and Wilby, R. (2007). Major droughts in England and Wales. Wea. 62, 87-93. doi:10.1002/wea.67

McCarthy, M., Christidis, N., Dunstone, N., Fereday, D., Kay, G., Klein-Tank, A., et al. (2019). Drivers of the UK summer heatwave of 2018. Wea. 74, 390-396. doi:10.1002/wea.3628

McKee, T. B., Doesken, N. J., and Kleist, J. (1993). The relationship of drought frequency and duration to time scales. Proceedings of the 8th conference on applied climatology, Anaheim, California, 17-22 January 1993. 179-183. 
Available at https://www.droughtmanagement.info/literature/AMS_Relationship_ Drought_Frequency_Duration_Time_Scales_1993.pdf (Accessed January 4, 2021).

Meempatta, L., Webb, A. J., Horne, A. C., Keogh, L. A., Loch, A., and Stewardson, M. J. (2019). Reviewing the decision-making behavior of irrigators. Wiley Interdiscip. Rev.-Water. 6 (5), e1366. doi:10.1002/wat2.1366

Morris, J., Graves, A., Daccache, A., Hess, T., Knox, J. (2010). "Towards a framework for the economic assessment of drought risk. An ecosystems approach" in Economics of drought and drought preparedness in a climate change context. Editor A. López-Francos ((Zaragoza, Spain: CIHEAM / FAO / ICARDA / GDAR / CEIGRAM / MARM), 139-148. Available at http://om. ciheam.org/om/pdf/a95/00801339.pdf

Morton, J., and Barton, D. (2002). Destocking as a drought-mitigation strategy: clarifying rationales and answering critiques. Disasters. 26, 213-228. doi:10. 1111/1467-7717.00201

Newton, A. C., Flavell, A. J., George, T. S., Leat, P., Mullholland, B., Ramsay, L., et al. (2011). Crops that feed the world 4. Barley: a resilient crop? Strengths and weaknesses in the context of food security. Food Security. 3 (2), 141-178. doi:10. 1007/s12571-011-0126-3

NFU (2018). Learning lessons from the 2018 agricultural drought. Available at: https://www.nfuonline.com/nfu-online/science-and-environment/climatechange/221-1118-leasons-learnt-drought-2018-final/ (Accessed July 17, 2020).

Ofwat and Environment Agency (2015). The case for change-reforming water abstraction management in England. Available at: https://www.ofwat.gov.uk/ wp-content/uploads/2015/11/pap_pos20111205abstraction.pdf (Accessed December 06, 2011).

Papadimitriou, L., D’Agostino, D., Borg, M., Hallett, S., Sakrabani, R., Thompson, A., et al. (2019). Developing a water strategy for sustainable irrigated agriculture in Mediterranean island communities-insights from Malta. Outlook Agric. 48 (2), 143-151. doi:10.1177/0030727019841060

Parsons, D., Rey, D., Tanguy, T., and Holman, I. P. (2019). Regional variations in the link between drought indices and reported agricultural impacts of drought. Agric. Syst. 173, 119-129. doi:10.1016/j.agsy.2019.02.015

Patton, M. Q. (1990). Qualitative evolution and research methods. 2nd edn. Newbury Park, CA, USA: Sage, 169-186.

Redman, C. L. (2014). Should sustainability and resilience be combined or remain distinct pursuits? Ecol. Soc. 19 (2), 37. doi:10.5751/ES-06390-190237

Rey, D., Holman, I. P., and Knox, J. W. (2017). Developing drought resilience in irrigated agriculture in the face of increasing water scarcity. Reg. Environ. Change. 17 (5), 1527-1540. doi:10.1007/s10113-017-1116-6

Rey, D., Holman, I. P., Daccache, A., Morris, J., Weatherhead, E. K., and Knox, J. W. (2016). Modelling and mapping the economic value of supplemental irrigation in a humid climate. Agric. Water Manag. 173, 13-22. doi:10.1016/j.agwat.2016.04.017

Rey, D., Holman, I. P., and Knox, J. W. [Data Collection](2019). Historic droughts inventory of references from agricultural media 1975-2012. Colchester, Essex: UK Data Archive.

Rial-Lovera, K., Davies, W. P., and Cannon, N. D. (2017). Implications of climate change predictions for UK cropping and prospects for possible mitigation: a review of challenges and potential responses. J. Sci. Food Agric. 97 (1), 17-32. doi:10.1002/jsfa.7767

Robinson, R. S. (2014). "Purposive sampling," in Encyclopedia of quality of life and well-being research. Editor A. C. Michalos (Dordrecht: Springer), 7347.

Rockstrom, J. (2003). Resilience building and water demand management for drought mitigation. Phys. Chem. Earth. 28 (20-27), 869-877. doi:10.1016/j.pce. 2003.08.009

Rodda, J. C., and Marsh, T. J. (2011). The 1975-76 Drought-a contemporary and retrospective review. Wallingford, Centre for Ecology and Hydrology. ISBN: 978-1-906698-24-9.
Rodriguez-Diaz, J. A., Weatherhead, E. K., Knox, J. W., and Camacho, E. (2007) Climate change impacts on irrigation water requirements in the Guadalquivir River Basin in Spain. Reg. Environ. Change. 7 (3), 149-159. doi:10.1007/s10113007-0035-3

Salmoral, G., Ababio, B., and Holman, I. P. (2020a). Drought impacts, coping responses and adaptation in the United Kingdom outdoor livestock sector: insights to increase drought resilience. Land. 9 (6), 202. 10.3390/land9060202

Salmoral, G., Holman, I. P., Ababio, B., Knox, J. W., and Rey, D. [Data Collection]. (2020b). Historic droughts inventory of references from agricultural media 2018. Colchester, Essex: UK Data Archive.

Toreti, A., Belward, A., Perez-Dominguez, I., Naumann, G., Luterbacher, J., Cronie, O., et al. (2019). The exceptional 2018 European water seesaw calls for action on adaptation. Earths Future. 7, 652-663. doi:10.1029/2019EF001170

United Utilities (2018). Temporary ban on water use.Available at: https://www. unitedutilities.com/globalassets/documents/tubfinalweb.pdf (Accessed July 22, 2020).

Vicente-Serrano, S. M., Beguería, S., Lopez, J., and Moreno, I. (2010). A multiscalar drought index sensitive to global warming: the standardized precipitation evapotranspiration index. J. Clim. 23, 1696-1718. 10.1175/2009JCLI2909.1

Viederman, S. (1994). Five capitals and three pillars of sustainability. The Newsletter of PEGS. 4 (1), 5-12.

Vogel, A., Scherer-Lorenzen, M., and Weigelt, A. (2012). Grassland resistance and resilience after drought depends on management intensity and species richness. PloS One. 7 (5), e36992. doi:10.1371/journal.pone.0036992

Waylen, K., and Martín-Ortega, J. (2018). Surveying views on payments for ecosystem services: implications for environmental management and research. Ecosyst. Serv. 29, 23-30. doi:10.1016/j.ecoser.2017.11.007

Weise, H., Auge, H., Baessler, C., and Barlund, I. (2020). Resilience trinity: safeguarding ecosystem functioning and services across three different time horizons and decision contexts. Oikos. 129 (4), 445-456 doi:10.1111/oik. 07213

Whaley, L., and Weatherhead, E. K. (2015). Power-sharing in the English lowlands? The political economy of farmer participation and cooperation in water governance. Water Altern. 8 (1), 820-843.

Wilhite, D. (2007). "Preparedness and coping strategies for agricultural drought risk management: recent progress and trends," in Managing weather and climate risks in agriculture. Editors M. V. K. Sivakumar and R.P. Motha (New York, NY, USA: Springer), 21-38.

WMO (2012). Standardized precipitation index user guide. Geneva: WMO-No 1090, 594.

World Weather Attribution (2018). Heatwave in northern Europe, summer 2018. Available at: https://www.worldweatherattribution.org/attribution-of-the2018-heat-in-northern-europe/ (Accessed July 28, 2018).

Wreford, A., and Adger, W. N. (2010). Adaptation in agriculture: historic effects of heat waves and droughts on United Kingdom agriculture. Int. J. Agric. Sustain 8, 278-289. doi:10.3763/ijas.2010.0482

Conflict of Interest: The authors declare that the research was conducted in the absence of any commercial or financial relationships that could be construed as a potential conflict of interest.

Copyright $\odot 2021$ Holman, Hess, Rey and Knox. This is an open-access article distributed under the terms of the Creative Commons Attribution License (CC BY). The use, distribution or reproduction in other forums is permitted, provided the original author(s) and the copyright owner(s) are credited and that the original publication in this journal is cited, in accordance with accepted academic practice. No use, distribution or reproduction is permitted which does not comply with these terms. 